\title{
PIONEER
}

VOLUME 11, Issue 2, December 2019: 105 - 115

\section{A MORPHOLOGICAL STUDY OF AFFIXES USED BY MAJOR AND MINOR CHARACTERS IN THE NOVEL THROUGH THE LOOKING GLASS}

\author{
Anggi Listiana Puspita Dewi \\ Bumigora University \\ langgi17@yahoo.com \\ Novian Zaini \\ Bumigora University \\ novianzaini@gmail.com \\ Puspita Dewi \\ Bumigora University \\ puspitadewi@universitasbumigora.ac.id
}

\begin{abstract}
This research is entitled A Morphological Study of Affixes Used by Major and Minor Characters in the Novel Through the Looking Glass. The objectives of this research are to identify the affixes, to find out the derivation and inflection changes used by characters in the novel Through the Looking Glass and to find out the most dominant affixes. The method of this research is qualitative research. The results of this research are: (1) affixes found at major characters are suffix, prefix, and confix. Afterward, affixes found at minor characters are suffix and prefix, (2) this research found 40 derivations and 85 inflection used by major characters. Besides, this research found six derivations and 17 inflections used by minor characters, and (3) the most dominant affix found at characters are suffix. In total of suffixes used by major character, there were 31 -ing, $10-\mathrm{ly}, 42-\mathrm{s}, 3-\mathrm{y}, 3$-able, 2 -ation, - -d, 15 -ed, 4 -er, 3 -es, 1-est, 2 -ful, 1 -ination, 1 -ish, 3 -ment, 1 -ness, 1 -or, 1 -ous, 1 -t, and 1 -th. Afterward, suffix found at minor characters there were 1 -ance, 4 -ing, 2 -es, $10-\mathrm{s}, 1-\mathrm{ly}$, and 1 -ed.
\end{abstract}

Keywords: affix, derivation, inflection, novel

\section{INTRODUCTION}

A story is supposed to be told to other. There are some ways to make story can be heard, for instance movie and novel. Movie and novel are part of literary work that delivers a story. On the other side, movie and novel are totally different. In movies there are some ways to make people understand the story, like expression of the actors, setting of places, and effect of voice and picture. However, in novel, the only thing that was appeared is only words which mean language has an important and main element in delivering a story. Besides, according to Watt (1957) novel has appeared since $18^{\text {th }}$ 
century when camera and film did not exist yet.

Few centuries have passed and novel is still loved by people. It is proved by the number of writer and how easy to find novels in this time. The role of novel in society cannot be separated from language choices and language styles which are able to hypnotize and make readers imagine the written story.

In a novel, there were characters that have important roles, because they would interact with other characters. In that interaction there would be words that are spoken by the character. According to Jago and Renee (2011), character is the second element of fiction after plot, because a plot can be created if an interaction between one character and other. From the definition, word that is uttered by character has an important role in a fiction. By reading and understanding the dialogue of characters, a reader knows the plot, the emotion can be touched and the message can be delivered. Therefore, character takes a part in this research. According to Aminuddin (1995), character has two types namely major and minor character. Major character is a character that has an important role and minor character is a character that has less important role than major character. The major character appearance dominates the minor character, because the function of minor character is to complete and support the major character.

In the previous paragraph, word that is used by the character is a main tool for an author to deliver his or her ideas. According to Quinn (in Sarumpaet 2010), literature is about typical writing, by utilization of a typical word and typical reading. Based on the definition, word is one of important elements in literature. Word is a group of letters which is a little thing in literature but it is deserved to be a spotlight because its function on literary work. By choosing a right word, the reader emotion can be touched and it is proved that the reader enjoyed its literary work.

Speaking about language choices, morphology is an appropriate study to analyze any data related to words. According to Samsuri (1988), morphology is a study field of linguistics and learns about structure and word forms. Word is the smallest element of language as a free morpheme (Sugono, 2008). Word can be followed with bound morpheme also known as affixation. Affixation is a group of letters that is supposed to stick with base words. So that, when base words are attached by affixation, they can become new words. Affixation is bound morpheme that consists of one or more 
segments that typically before, after, or within a base morpheme (Lieber, 2009). As we could see, affixation takes small part in word but it cannot be underestimated, because the affixation appearance can change the word class and its meaning. In affixation, derivation and inflection are terms that relate with word class changes. Derivation is about the changes of lexeme formation, syntactic category and adding different meaning (Lieber, 2009). According to Lieber (2009), inflection is about how category of word does not change and does not create a new lexeme in a word formation, but still inflection fits in a grammatical.

Based on the explanation, novel existences for centuries cannot be underestimated. In fact, the number of authors, novels released every year, and novel adaptation into a movie. One of phenomenal novel is Through the Looking Glass by Lewis Carrol. This novel was released in 1865 but it was nominated in two awardee programs in 2017 and has adapted as movie for five times those were 1928, 1966, 1973, 1998 and 2016. Besides, Carrol had written 111 literary works including poem and novel, so that Carrol must be have his own language style that is deserved to be analyzed. Thus, this research aims to analyze affixes used by the major and minor characters in the novel Through the Looking Glass by Lewis Carrol. Affixes are the smallest unit in a word but it is not as simple as that because it could affect in some other elements, such as the changes of word class and the meaning in a word. Therefore, this research discusses about affixation that is used in the novel Through the Looking Glass by Lewis Carrol especially by the major and minor characters.

This research focuses on fiction novel Through the Looking Glass by Lewis Carrol that was released in 1865 . It contains 144 pages, and 12 chapters published by Gramedia Pustaka Utama in Indonesia and written in English. This research analyzed affixes that appear in dialogue of major and minor characters in this novel. The research problems are a) what are the most dominant affixes used by the major and minor characters in the novel Through the Looking Glass? b) what is the process of derivation and inflection used by the major and minor characters in the novel Through the Looking Glass? 


\section{REVIEW OF LITERATURE}

\section{Literary Work}

According to Wellek and Warren (1987), literature is creativity of an art. It means that a literature is expression of someone's about everything that stated in a literary work. According to Musthafa (2008), the nature of literature is about a line of event and focused in some characters. It is about ability, decision, knowledge, sensitivity, value of its characters which relates to the problem that character face. According to Musthafa (2008), there are some types of literary work, they are fiction prose, poetry, drama, and non-fiction prose.

\section{Fiction prose}

This type is about myth, parable, romance and novel

\section{Poetry}

Poetry is about a literary work as a place to express their idea, emotion, imagination and reflection in a small place. The rhyme of poetry is also for strengthen the effect of its work.

\section{Drama}

The function of drama is to show a literature work on a stage for audience. The nature of this type is about how literature work delivers by move and oral.

\section{Non-fiction prose}

The characteristic of non-fiction prose is about fact that equipped by opinion and judgment. The example of non-fiction prose is article, essay, editorial, biography and historical things and others.

\section{Morphology}

According to Samsuri (1988), morphology is a study in the field of linguistics which learns about structure and word forms. Morphology is a study about word. There are two morphemes in morphology, bound morpheme such as affixation and free morpheme such as word. In linguistics, morphology is part of micro linguistic. According to Bloomfield (1933), morphology is a study that analyzes about word and part of words especially when bound morpheme appears on it.

According to Aartz (2014), the smallest unit that is appeared in morphology and word formation is named morpheme. Stem, roots and affixes is included into types of 
morpheme. These terms also known as free morpheme and bound morpheme.

\section{Inflection and Derivation}

According to Lieber (2009), inflectional is about how category of word does not change and does not create a new lexeme in a word formation, but still inflectional fits in a grammatical. Grammatical means about an information or numbers (singular or plural), person (first, second and third), tense (past, present, future) and the others.

According to Lieber (2009), derivation is about the changes of lexeme formation, syntactic category and adding different meaning. According to Chaer (2007), derivation is about how a new word creates that lexical identity and the base word are not the same. Mostly the changes are related with the class word.

\section{Characters and Characterization}

According to Jago and Renee (2011), character is the second element of fiction after plot; because a plot can be created if an interaction between one character and others are appear. So that, character is representative of a person that has events whether incident, conflict and so on. According to Aminuddin (1995), character has two types, major and minor characters.

\section{Major characters}

Major character is the character that has important role compared with other characters (Aminuddin, 1995). The criteria of major character are not about the number appearance in the story but the intensity of its involvement and major character appearance dominates the minor character. From the definition, major character is about the center of attention the author and reader and able to arouse reader emotion. Protagonist and antagonist are included in major character. The major characters that were discussed in this research are Alice, Humpty Dumpty, Red Queen, White King, and White Queen.

\section{Minor characters}

Minor character is a character that has less important role than major character (Aminuddin, 1995). From the definition, the role of minor characters is the opposite of major characters but the minor characters are used to support the major character role and minor character appearance does not dominate the story. The minor characters that 
were discussed in this research are Guard, White paper dress man, Hoarse, Gnat, No Name 1, No Name 2, The Frog, The Pudding.

According to Jago and Renee (2011), characterization is divided into direct characterization and indirect characterization. Direct characterization is the background, motivation, temperament or appearance is described specifically. Besides, indirect characterization is showed the character by showing what characters say, do, think or by the interaction between other characters.

\section{METHOD}

\section{Research Method}

Research method is about the tool how to get the relevant data. Research method is a multi-step scientific activity that is started from topic determination, collecting data and data analysis to find out understanding in certain topic, phenomenon and issues (Raco, 2010). This research is qualitative research that looks for insights of phenomenon, facts or reality deeply (Raco, 2010). So that research qualitative is a research that discusses about phenomenon that cannot be measured by number. This research had two stages of getting data, data collection and data analysis (Sudaryanto, 2015).

\section{Data Collection}

Data collection is the part of research methodological which is a process to collect the data that is needed in a research. This is a process to get valid and reliable data. The data that is collected is related with research problem so that the data that is collected is clear enough whether in the number or classification of the data because that is how to consider in choosing data. Transkripsi kemorfeman is a type of data collection that is related with morphemes (Sudaryanto, 2015). From the definition, this research is about Transkripsi Kemorfeman because of the data that is needed is affixation that appears on the novel Through the Looking Glass by Lewis Carrol. Here are some stages in collecting the data.

First, reading the novel carefully and find out the number of pages, chapters and characters that is communicating with another characters. This is the second step of data collection, while reading the data, researcher notices the communication between the 
characters. In that conversation, there where be affixes that are used by the characters and that data is what a research need. The last step of data collection is classifying the data. Right after underlined the data, next, classifies it into the affixes type column. This is a step to ease in analyzing the data.

\section{Data Analysis}

Data analysis happens after the data collection finish and the data has collected. Data analysis is the main point then solves the problem that appears on the data. Metode Agih is a data analysis stage which is language as the main determine of the research such as words, syntaxes function, clause syllable and so on (Sudaryanto, 2015). In this research, the data were analyzed suffixes used that appear in the novel Through the Looking Glass as part word. In this stage, researcher analyzed the word class changes after suffixes added and analyzed the changes meaning after suffixes added. Here, were some stages in analyzing the data.

Cambridge dictionary was used in this research used to find the meaning of base word and the word that was attached by affixes. After looking up at the dictionary, the next step was finding the word classes after the affixes were attached to the word. Right after finding the word class, the last step was deciding if the word inflection or derivation.

\section{FINDING AND DISCUSSION}

\section{Findings}

This research found 134 affixes used by major characters and 22 affixes used by minor characters. In major characters, there were two prefixes, 19 suffixes, and four confixes. Besides, in minor characters there were one prefix and six suffixes.

\section{Percentage of affixes found at major character}

In this part, the percentage of affixes that found at major characters would be shown. 


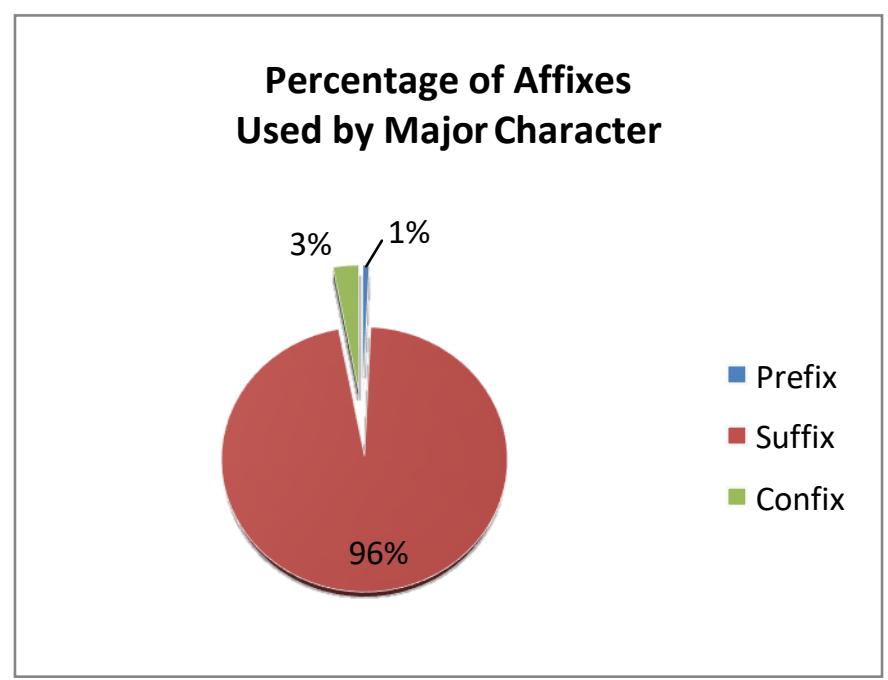

Figure 1. Percentages of Affixes found at Major Characters

\section{Percentage of affixes found at minor character}

In this part, the percentage of affixes that found at Minor characters would be shown.

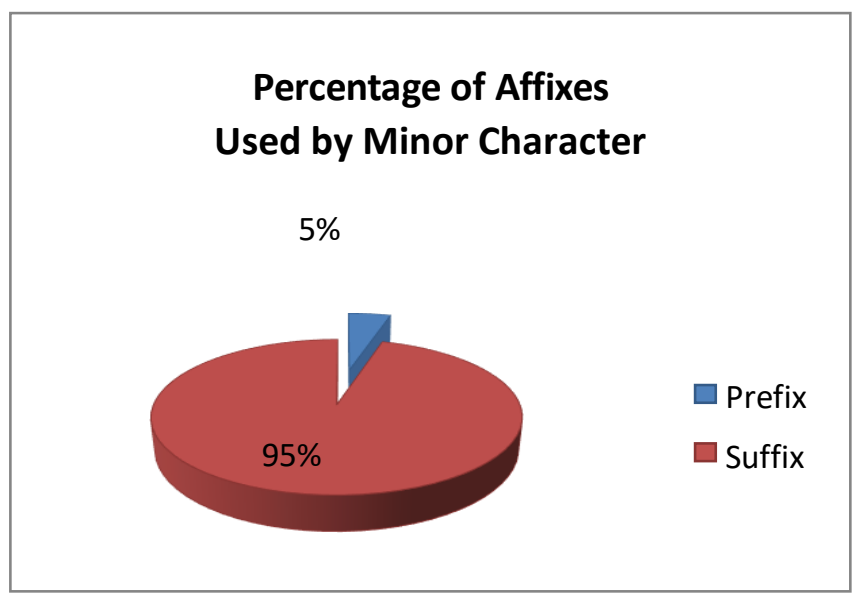

Figure 2. Percentages of Affixes found at Minor Characters

\section{Discussion}

According to Chaer (2007), affixation divided into some types such as prefix, infix, suffix, confix, interfix, and circumfix. However, this research did not find infix, interfix and circumfix. In this research, there were affixes prefix, suffix and confix that was used by major characters. This research found prefix in-, un- and a-, in terms of suffix, this research found suffix -es, -ination, -ing, ish, -ly, -ment, -s, -y, -able, -ation, d, -ed, -er, -est, -ful, -ness, -or, -ous, and -th. In terms of confix, this research found im-ability, dis- -ful, dis- -ed, un- -able. Besides, there were affixes prefix and suffix that was used by minor characters. This research found prefix re-. In terms of suffix, there 
were -ance, -ed, -es, -ing, -ly, and -s. Related to affixes that were mentioned by Hanafi (2017), there were some affixes used by major character that was not included into his list. Such as prefix in-, suffix es, -ination, -ing, ish, - ly, -ment, -s, -y, -able, -ation, -d, ed, -er, -est, -ful, -ness, -ous, and -th also confix im- - ability, dis- -ful, dis- -ed. There were some affixes used by minor character that was not included into his list. Such as suffix -ance, -ed, -es, -ing, -ly and -s. Related to Yuwono (2017), analyze about Derivational Affixes Found in E.B White's Novel Charlotte's Web and Its Application in Teaching Vocabulary at the Tenth Grade of Senior High School, he did not find suffix -ing, -ed, -y, -or, -th, -ability, and -ance that affect to derivational process. However, related to research by Aryati (2014), analyze about Derivational Affixes in The Land of Five Towers Novel by A. Fuadi Translated by Angie Kilbane derivational affixes in The Land of Five Towers Novel by A. Fuadi, this research did not find suffix -ing, -ion, -ed, -y, -th and -ability.

This research found 40 derivations and 85 inflections used by major characters. Besides, this research found six derivations and 17 inflections used by minor characters. According to Lieber (2009), inflectional is about how category of word does not change and does not create a new lexeme in a word formation, but still inflectional fits in a grammatical. Grammatical means about an information or numbers (singular or plural), person (first, second and third), tense (past, present, future). In this research, numbers (singular or plural), person (first, second and third), tense (past, present, future) became some important elements of Inflections.

In total, there were one prefix, 129 suffixes, four confixes used by major characters. Also, there were one prefix and 21 suffixes used by minor characters. This research found that suffix was the most dominant affix used by major and minor characters. In total of suffixes used by major character, there were 31 -ing , 10 -ly, 42 s, 3 -y, 3 -able, 1 -ation, - -d, 15-ed, 4 -er, 3 -es, 1 -est, 2 -ful, 1 -ination, 1 -ish, 3 ment, 1 -ness, 1 -or, 1 -ous, 1 -t, and 1 -th.

\section{CONCLUSION AND SUGGESTIONS}

\section{Conclusion}

In summary, the affixes used by major character are prefix, suffix and confix. This research found prefix in-, un- and a-, in terms of suffix this research found suffix - 
es, -ing, ish, -ly,-ment, -s, -y, -able, -ation, -d, -ed, -er, -est, -ful, -ness, -or, -ous, and th. In terms of confix this research found im- -ability, dis- -ful, dis- -ed, un- -able. However, minor character used affixes namely prefix and suffix. This research found prefixes re-. In terms of suffix there were -ance, -ed, -es, -ing, -ly, and -s. The most dominant affix used by major and minor characters is suffix. There were $31-\mathrm{ing}, 10-$ ly, 42 -s, 3 -y, 3 -able, 3 -ation, 1 -d, 15 -ed, 4 -er, 3 -es, 1 -est, 2 -ful, 1 -ish, 3 ment, 1 -ness, 1 -or, 1 -ous, 1 -t, and 1 -th. In total there were 129 suffixes found at major characters. Afterward, suffix found at minor characters there were 1 -ance, 6 ing, 2 -es, $10-\mathrm{s}, 1-\mathrm{ly}$, and 1 -ed. In total there were 21 suffixes found at minor characters. This research found the process of derivations are prefix a-, and suffix ment, -ed, -ing, -ly, -ation, -ful, -y, -ish, -ness, -ous, -able, -or, -th, and -ance. The process of inflections are prefix un-, in-, and suffix -s, -ed, -ing, -ed, -ing, -er, -est, ation, -t, -ly. There were 40 derivations and 85 inflections used by major characters. Besides, this research found six derivations and 17 inflections used by minor characters.

\section{Suggestion}

By reading this research, the students know about derivation and inflection process, especially affixes used by major and minor characters in literary work. To the lecturers, especially who teaches Morphology, the lecturers are suggested to give explanation and understanding about derivation and inflection deeply. Because, based on this research, derivation and inflection are not simple. To the further researchers especially for those who want to analyze in the same field, they are suggested to look at carefully the meaning before and after affixes are attached. Besides, the further researchers are suggested to have enough time finishing their research.

\section{REFERENCES}

Aminuddin. (1995). Stilistika: Pengantar Memahami Bahasa dalam Karya Sastra. Semarang: IKIP Semarang Press.

Aryati, M,S. (2014). "An Analysis of Derivational Affixes in The Land of Five Towers Novel by A. Fuadi Translated by Angie Kilbane." Kudus (ID): Universitas Muria Kudus.

Bloomfield, L. (1993). Language. New York: Holt, Rinehat and Winston. 
Chaer, A. (2007). Linguistik Umum Edisi Ketiga. Jakarta: Rineka Cipta

Hanafi, N. (2017). Morphology. Mataram: Mataram University Press

Jago, C, et.al. (2011). Literature \& Composition. USA: Bedford-St Martin.

Lieber, R. (2009). Introducing Morphology. USA: Cambridge University Press.

Musthafa, B. (2008). Teori dan Praktik Sastra dalam Penelitian dan Pengajaran. Jakarta: PT. Cahaya Insan Sejahtera.

Raco, J. (2010). Metode Penelitian Kualitatif: Jenis, Karakteristik dan Keunggulannya. Jakarta: PT. Grasindo.

Samsuri. (1988). Morfologi dalam Pembentukan Kata. Jakarta: Proyek Pengembangan Lembaga Pendidikan Tenaga Kependidikan.

Sarumpaet, R. (2010). Pedoman Penelitian Sastra Anak. Jakarta: Pusat Bahasa Kementerian Nasional.

Sudaryanto. (2015). Metode dan Aneka Teknik Analisis Bahasa. Yogyakarta: Duta Wacana University.

Sugono, et.al. (2008). Kamus Besar Bahasa Indonesia. Jakarta: Pusat Bahasa Departemen Pendidikan Nasional.

Watt, I. (1957). The Rise of the Novel. California: University of California Press.

Yuwono, R. (2017). 'Derivational Affixes Found in E.B White's Novel Charlotte's Web and Its Application in Teaching Vocabulary at the Tenth Grade of Senior High School.” Tulung Agung: IAIN Tulung Agung 